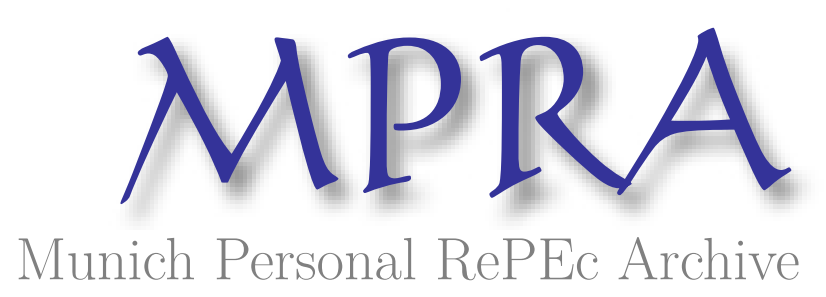

\title{
Employment generation in Brazilian coffee regions
}

Bliska, Flavia M. M. and Guilhoto, Joaquim J. M. and Imori, Denise and Sakon, Fernando M. and Camargo, Fernanda S. and Vegro, Celso L. R.

Coffee Center, Agronomic Institute, University of São Paulo, Institute of Agricultural Economy

2009

Online at https://mpra.ub.uni-muenchen.de/30729/

MPRA Paper No. 30729, posted 05 May 2011 18:56 UTC 


\title{
EMPLOYMENT GENERATION IN BRAZILIAN COFFEE REGIONS
}

\author{
Flavia M. M. Bliska ${ }^{1}$, Joaquim J. M. Guilhoto ${ }^{2}$, Denise Imori ${ }^{2}$, Fernando M. Sakon ${ }^{2}$, \\ Fernanda S. Camargo ${ }^{2}$, Celso L. R. Vegro ${ }^{3}$
}

Due to the specific characteristics of coffee production on each of the main Brazilian states producers of arabica (Coffea arabica) and robusta coffee (Coffea canephora), a better understanding of the structural links between production and industrialization of coffee on those states and the national economy can provide subsides for implementation of public policies, essential to plan the coffee production and increase the sector competitiveness. Therefore, this study analyzed the employment generation in production and coffee industrialization in the major Brazilian production regions, based on an inter-regional input-output model, with seven regions, which represent the main coffee-producing states - Minas Gerais, Espirito Santo, São Paulo, Paraná, Bahia and Other States - with 44 sectors each, in a system of 308 sectors. The results indicated that the production of robusta coffee is the sector that generates more employments (total) per currency unit, and that arabica production sector is the fourth largest generator of employments, among the 44 sectors considered for the country. The results for each state emphasized the importance of farming and coffee industry for national and state economies.

\footnotetext{
${ }^{1}$ Coffee Center, Agronomic Institute, IAC, Av. Barão de Itapura, 1481, Campinas, SP, 13098-344, Brazil, 5519 3241-5188, Fax 5519 3212-0458, bliska@iac.sp.gov.br

${ }^{2}$ University of São Paulo, Av. Prof. Luciano Gualberto, 908, FEA I - Cidade Universitária, São Paulo, SP, 05508-900, Brazil, 5511 3091-5802 / 03, Fax 5511 3091-6013, guilhoto@usp.br, denise.imori@gmail.com, fsakon@gmail.com, sartori.f@gmail.com ${ }^{3}$ Institute of Agricultural Economy, Av. Miguel Stéfano, 3900, Água Funda, Sao Paulo, 04301-903, Brazil, 5511 5087-0468, Fax 5511 5073-4062, celvegro@iea.sp.gov.br
} 


\section{INTRODUCTION}

The coffee crop was introduced in Brazil at the beginning of the eighteenth century. Nowadays its production is dispersed on a large part of the national territory. The migratory character/ aspect of the coffee production remains from the colonial era, and resulted in relevant geographical shifts and structural changes in the Brazilian coffee production. While the coffee production is widespread in the country, it is currently concentrated in six states: Minas Gerais, Espírito Santo, São Paulo, Paraná, Bahia and Rondônia. The diversity of social, cultural and, especially, environmental conditions such as soil, topography, altitude, latitude and rainfall indices - in each of those states, resulted not only in different producing regions and types of coffee, but also in different structures of production, technology and competitiveness.

Thus, in the states of Minas Gerais, São Paulo and Bahia the culture of Coffea arabica, known as arabica coffee, is predominant, while in the states of Espirito Santo and Rondonia dominates the culture of Coffea canephora, generally known as robusta coffee (Conillon variety), that is used mainly in the coffee industry or in blends with arabica coffee.

For many decades, coffee was the main product of Brazilian exports, and despite the reduction of its share in those exports, is still very important for the country, especially on the social aspect. It is present in at least 370 thousand rural properties, $70 \%$ of them with familiar character, distributed in 2000 municipalities, in 17 States of the Federation. Furthermore, the manual harvesting accounts for great part of agricultural employment, and for up to $50 \%$ of the costs of their production.

Each one of those producing states presents segments of their respective coffee production chains with distinct structural and technological levels. However, in most producing regions the prevail production systems is based on coffee intensive labor, 
especially during the harvesting, that can extend from May to September, due the region and climate.

Due to technological and structural characteristics of the coffee sector, in each region of arabica and robusta coffee, where seasonal and intensive use of labor occurs, this study aims to provide subsidies to improve the understanding of structural relationships between coffee production and industrialization sectors and the national economy. Another goal is to provide subsidies for implementation of public policies, planning of the coffee park and to increase the competitiveness of the national coffee in general.

\section{METODOLOGY}

To analyze the behavior and current importance of the sectors of agricultural production and industrialization of coffee for each of the main Brazilian producers, for their respective state economies and other sectors of national economy, regarding to generation and expansion of employments, it was built an inter-regional input-output model, for the year 2002. This system has seven regions and 44 sectors per region, a total of 308 sectors, and it is consistent with the productive structure of the Brazilian economy, which is reflected in the reformulation of the System of National Accounts, occurred in 2007.

The survey of structures and technical coefficients of/ for production of arabica and robusta coffee, in the main producer states - Minas Gerais, Espírito Santo, São Paulo, Paraná, Bahia and Rondônia - was conducted between September 2005 and August 2006. This survey was used as a parameter to build the inter-regional input-output model, with seven regions, representing, respectively, those six major producer states and the region RBR, which include other Brazilian states where coffee production is not significant or there is no coffee production at all. 
For the survey, i a structured questionnaire was administered, developed in partnership with experts from the Institute of Agricultural Economics - IEA and Embrapa Café, based on published information on costs of coffee production in Brazil. Different models used by cooperatives, universities, consultants in the industry and the National Supply Company - CONAB (in Portuguese abbreviation) were adjusted.

The structures of production cost were used to extract the sector of coffee production (beans) from the other sectors of agricultural production in the matrix inter-regional original - called "Agriculture". The sector of coffee industrialization was already dissociated from the other sectors of the agricultural products industrialization.

The input-output model, in its original formulation, assumes that the relative price of the system remain constant. Due/ based on that assumption, the effects simulated in the system are obtained in terms of quantity. As price-effects may have different consequences, depending on their cause - in the case of coffee, loss of harvest, variations in costs of inputs, changes in the international prices, among others - a construction of sophisticated models of computable general equilibrium would be required to analyze those effects, which escapes the scope of this work. As this study focuses on structural analysis of the coffee sector, the input-output model is more reasonable, particularly for long-term analysis, concerned with the structure of production processes.

To reduce the impact of lag time between the data collected - such as prices, quantities of raw and wages - some information on the changes in levels of inputs and machinery used in the period 2002/2005 (fertilizer, pesticides and other chemical inputs / tractors, mowing machines and other) were also raised in the applied questionaire. Indications of change in any of these variables resulted in correction of the value used in the opening of the input- 
output matrices, based on the estimative(s) of the interviewee(s), regarding to the rate of change in the respective region, between 2002 and the date of questionnaire application. That is, an estimate of the values and prices in 2002 was performed.

The data obtained via questionnaires were compared with secondary data provided by government agencies, research institutes and cooperatives related to the coffee sector. The values of production of coffee in each producing region were estimated based on 2002 prices. To estimate the profits were also used estimates of prices paid and received by producers in 2002 .

This paper specifically examined the direct, indirect and induced effects of employment generating/ or generation?, and the effects of employment multiplier, Type I and Type II, for the sectors and countries that compose the system, detailed below.

The vector "busy people" of the national input-output matrix was taken out directly from the new system of national accounts, which was based on the National Survey by Household Sample (PNAD - IBGE, 2002) to open up sectors related to coffee. For regionalization, that is, construction of an inter-regional input-output system, data from PNAD (IBGE, 2002) were used as the basis for opening of the sector "occupied people", beside other specific sources about the culture of coffee/ or coffee cultivation? The vector "employed persons" of the national input-output matrix was taken out directly from the new system of national accounts, which was based on the National Survey by Household Sample (PNAD - IBGE, 2002) to open up sectors related to coffee. 


\section{Theoretical background}

The intersectorial flows in a specific economy are determined by technological and economic factors, and these flows can be described by the following system:

$$
A X+Y=X
$$

where $X$ is a (n $\mathrm{x} 1$ ) vector, with the value of the total production in each sector; $A$ is a ( $\mathrm{x} \times \mathrm{n}$ ) matrix with the technical coefficients of production (Leontief, 1951); and $Y$ is a ( $\mathrm{n} \times 1$ ) vector with values for the final demand. In this model, the final demand vector can be treated as exogenous to the system, such that the level of total production can be determined by the final demand, i.e.

$$
\begin{gathered}
X=B Y \\
B=(I-A)^{-1}
\end{gathered}
$$

where $B$ is a (n $\mathrm{x} \mathrm{n})$ matrix of the Leontief inverse.

From equation (3) it is possible to evaluate the impact of the final demand over total production, and from there, over employment, imports, wages, and others.

\section{Induced effect model}

The employment effects can be classified into three types: a) direct employment effect, that determines how many employments are generated by a given sector when its production is increased; b) indirect employment effect, that determines how many employments are generated in all the other sectors when the production of a given sector is increased; and c) induced employment effect, that determines how many employments are generated as a result of households' consumption, in consequence of rise in their income, given the increase of direct, indirect and induced employments. 
To estimate the induced effect, i.e., how much the increase in employment would generate, for instance, over total production in the economy, given the consumption of the newly employed people, one can make the family consumption and family income endogenous in the model, and we instead $A$ we will have:

$$
\bar{A}=\left[\begin{array}{cc}
A & H_{c} \\
H_{r} & 0
\end{array}\right]
$$

where $\bar{A}$ is the new matrix of technical coefficients with size $((\mathrm{n}+1) \mathrm{x}(\mathrm{n}+1))$, and $\left(\mathrm{H}_{\mathrm{r}}\right)$ is a $(1 \times n)$ vector with the income coefficient in each sector and $\left(H_{c}\right)$ is a $(n \times 1)$ vector with the families' consumption coefficients.

As so, the new vectors of production and final demand would be given, respectively, by $(\bar{X},(\mathrm{n}+1) \mathrm{x} 1)$, and by $(\bar{Y},(\mathrm{n}+1) \mathrm{x} 1)$, that would be represented as

$$
\begin{aligned}
& \bar{X}=\left[\begin{array}{c}
X \\
X_{n+1}
\end{array}\right] \\
& \bar{Y}=\left[\begin{array}{c}
Y^{*} \\
Y^{*}{ }_{n+1}
\end{array}\right]
\end{aligned}
$$

where $\bar{B}$ is a $((n+1) x(n+1))$ matrix of the Leontief inverse, tanking into consideration the induced effect, and the Leontief system would be represented as

$$
\begin{gathered}
\bar{X}=\bar{B} \bar{Y} \\
\bar{B}=(I-\bar{A})^{-1}
\end{gathered}
$$

\section{Production multipliers}

From the multipliers results it is possible to measure the direct and indirect effects of a change in the final demand over productions, income, employment and others (Miller and Blair, 1985). From the Leontief inverse matrix $(B)$, defined above, we have that the 
production multipliers of Type I, for each economic sector, is given by

$$
M P_{j}=\sum_{i=1}^{n} b_{i j} \quad \mathrm{j}=1, \ldots, \mathrm{n}
$$

where $M P_{j}$ is the production multiplier for each $j$ sector and $b_{i j}$ is an element of matrix $B$.

The production multiplier of type II, that takes into consideration the induced effect, is given by

$$
\begin{gathered}
\bar{P}_{j}=\sum_{i=1}^{n} \bar{b}_{i j} \\
j=1, \ldots, n
\end{gathered}
$$

where $\bar{P}_{j}$ is the production multiplier for sector $j$ and $\bar{b}_{i j}$ is an element of matrix $\bar{B}$.

\section{Coefficients and employment generation}

To estimate the employment multipliers, one first go by estimating the coefficients of employment, given by

$$
w_{j}=\frac{e_{j}}{x_{j}}
$$

where $w_{j}$ is the coefficient of employment in sector $j, e_{j}$ is the total employment in sector $j$, and $x_{j}$ is the level of production in sector $j$.

The total employment of type I ( $\left.E_{j}\right)$ and type II ( $\left.\bar{E}_{j}\right)$, generated in sector $j$ are given by

$$
\begin{aligned}
& E_{j}=\sum_{i=1}^{n} w_{i} b_{i j} \\
& \bar{E}_{j}=\sum_{i=1}^{n} w_{i} \bar{b}_{i j}
\end{aligned}
$$

where $b_{i j}$ and $\bar{b}_{i j}$ are elements of the matrices $B$ and $\bar{B}$ described above. 
The employment multipliers, i.e., how much employment is generated in the economy for each person employed in a given sector, is given by equations (14) and (15) below, for the cases of the type I $\left(W_{j}\right)$ and type II $\left(\bar{W}_{j}\right)$ multipliers

$$
\begin{gathered}
W_{j}=\frac{E_{j}}{w_{j}} \\
\bar{W}_{j}=\frac{\bar{E}_{j}}{w_{j}}
\end{gathered}
$$

\section{RESULTS}

To facilitate the understanding of the relationship occurring among employment coefficient, coefficient of employment multiplication (or multiplier) and coefficient of employment generation (or generator), the results obtained by applying the proposed methodology are presented in tables 1 to 8 .

\subsection{Results for Brazil}

In this section are evaluated the results obtained by multipliers and employment generation coefficients calculated for Brazil. The coefficients are interpreted in accordance with descriptive analysis performed from/ on data extracted directly from the input-output matrices. Subsequently, the results for each state are incorporated, allowing the comparison of generation and demand for labor in different sectors present in each state.

\section{Multipliers, generators and descriptive analysis of the input-output matrix}

The direct, indirect and induced effects of employment generating/ or generation?, and type I and type II multipliers, for sectors of the input-output matrix, built to analyze the sectors directly related to coffee, are presented at table 1 (the values of employment 
generate effects are expressed in the Brazilian currency - Reais, in constant prices of 2002).

The five sectors that generate more employments (total), per 1 million reais, are: "Robusta Coffee", "Non-market private services", "Other Agricultural Products", "Coffee Arabica" and "Articles of clothing".

Two parameters will be explored below: the employment generating coefficients and employment multipliers. The analysis with the employment generating coefficients will be evaluated more specifically, once it focuses on the best size and production activities and its relations with the labor market.

\section{The employment generator}

The direct, indirect and induced coefficients of employment generation are related to the amount of employments and the monetary values (also expressed in the Brazilian currency - Reais in constant prices, millions of real employments by 2002).

The total effect of an increase of one million reais on the production of arabica coffee creates/ is an increase of 121 direct employments, 14 indirect and 71 induced, , a total of 207 employments. Also generates 192 direct employments, 20 indirect and 74 induced in the case of robusta, a total of 286 employments.

In the nineteenth century coffee crop was considered an activity of great social importance, due to the generation of employments in farming and industry. However, although the Brazilian coffee agribusiness has been internalized, with new techniques of production, post-harvesting, processing and marketing - such as the launch of new genetically superior materials, the density of cultivation, the irrigation use, the introduction of mechanical harvesting and the spread of good harvest and post harvest 
practices - with positive impacts on productivity and quality of the final product, the results of the input-output analysis indicate that arabica and robusta coffees still use intensive labor-work.

The mechanical harvesting is limited to small portion of arabica crop, according to the limitations imposed by the soil slope of some producing regions, such as southern state of Minas Gerais. Also depending on the existence of economies of scale, the use of mechanical harvesting is limited to medium and large farms, especially in the western region of Bahia, in the Cerrado of Minas Gerais, some areas of southern Minas Gerais and in some regions of São Paulo State. Even in medium size farms, the use of mechanical harvesting is often possible only via outsourcing, rental of machinery or joint purchasing, via cooperatives or farmers associations. There is equipment to help harvest in small farms - vibrators, with system of "finger" to help overthrow the grains, which reduce the use of labor, but not in the same proportion as the major machines. Since up to $70 \%$ of Brazilian producers have less than 50ha of coffee, the use of labor in these farms is still strong.

The greater importance of robusta coffee for employment generation, compared to arabica coffee, can be explained by the inability to perform the mechanical harvesting. The fruits of robusta coffee are more strongly stuck in the branches than fruits of arabica, and an efficient system of mechanical harvesting for robusta coffee is not yet available.

With respect/ Regarding to the coffee industry, it was found that this sector had the 8thhighest rate of employment generation, among the 44 sectors of the economy, higher than the position obtained by traditional sectors in the Brazilian agribusiness, such as "Manufacturing of sugar", "Vegetable oils" and "Dairy" and also higher than sectors such as shoes, Chemistry, Pharmacy. 


\section{The employment multiplier}

As seen above, one can divide the employment multiplier into the following types: Type I multiplier, which determines how many employments are create directly and indirectly from the creation of a new post in a particular productive sector; and multiplier Type II, that add to the Type I employment multiplier the employment resulting from the increase in the population income due to the greater quantity of direct and indirect employment.

As for the multiplier effects, the results presented in Table 1 indicate that the sectors of "Robusta" and "Arabica" coffee have the two smaller effects among the 44 sectors of the economy. In contrast, the coffee industry presents the 5th-largest multiplier effect, which again indicates the importance of coffee agribusiness for the Brazilian economy. Therefore, the results indicated that the sectors of production of arabica and robusta coffee are important in generating a large volume of employments, direct, indirect, and induced, by unit currency produced in the final demand, expressed in reais, compared to other sectors of the Brazilian economy or state economies.

However, these sectors are not able to multiply the number of employments when you create a new working post in the industry, or are not able to generate employment from the increase of income of the population resulting from the creation of new employments.

\subsection{Results for Brazilian states}

In this section, results of the coefficient of direct employment, the direct, indirect and induced employment generating, and the values of employment multipliers for the sectors and states of the system in 2002 are presented. That is, the importance of 
employment generating and employment multipliers, were analyzed, in states where the sectors related to coffee have significant participation.

Basically, the results indicate that the sectors "Robusta", "Arabica" and "Coffee Industry" are generally among these with the largest employment generators in Brazil, by the currency unit in final demand, and we emphasize that the values of those generators stems mainly from its induced effects.

Therefore, public policies that stimulate those production sectors should contribute to the employment increase, or at least for its maintenance.

In the states where the coffee sector has great participation, the employment generating effect provides a singular focus forward/ or towards? to the other sectors. In the State of Minas Gerais, the largest Brazilian producer of arabica coffee, accounting for about $50 \%$ of the total volume produced, the employment generator (total) of the "Arabica" and "Coffee Industry", are, respectively, the second and seventh, between the largest generators of employment in the period.

In the State of Espírito Santo, coffee sectors are among the five largest generators of total employments: first place for "Robusta", third for "Arabica" and fourth place for "Coffee industry". This result is consistent with socioeconomic indicators for that State, because Espírito Santo is the largest Brazilian producer of robusta coffee, a large exporter, and has large number of coffee roasting and soluble coffee industries . In addition, coffee is frequently present in its farms, most of them are small or family business, and the harvest mechanization is not significant.

In São Paulo State only the sectors of "Coffee industry" and "Arabica" stand out, since there is no production of robusta coffee in that State. The "Arabica" sector is the third 
largest employment generator among 44 sectors of the state, while the sector "Coffee Industry" (roasting and solubilizing) is the eighth largest employment generator in the state. Despite the diversity of Sao Paulo industries, which represent many sectors of the state economy, there is a concentration of industry, for roasting and grinding of coffee in this state, as well as solubilizing industries.

In the State of Paraná, "Arabica" was the sector that generated most part of total employment in 2002, highlighting the importance of Coffea arabica for this state. This result reflects the land structure of the two main regions of coffee production in the Paraná State - the "Norte Velho", represented by the region of Jacarezinho and "Norte Novo", represented by the region of Cornélio Procópio - where dominate properties between 4 and 8 ha, high density production system, intermediate technological level, and above all, family labor, except in periods of harvest, when the demand for hired labor increases. The "Robusta" sector also stands out in the following States: Bahia, the third largest Brazilian producer of robusta coffee, with the 3rd largest employment generator; Rondônia, the second largest Brazilian producer of robusta, the 2nd largest employment generator in the state; and also in Rest of Brazil, because in all the other Brazilian states, the cultivation of robusta coffee presents the biggest/ largest employment generator.

\section{CONCLUSIONS}

In summary, the analysis of the matrix for Brazil show us that the production of robusta coffee is the sector that generates more employments (total) per 1 million of reais, while production of arabica coffee is the fourth largest employment generator, among 44 sectors considered. 
Regarding the employment multipliers, Type I and Type II, the coffee industry had the fifth largest multiplier among the 44 sectors, but there are no indications that the production of arabica and robusta coffee is significant as employment multiplier, from the creation of a new employment, or from increasing the income of the population due to the creation of a new employment.

The results also indicated that for Minas Gerais State, the generators of total employment of "Arabica" and "Industry coffee" are, respectively, the second and seventh largest coefficients in the period. That is, in the state responsible for $50 \%$ of national coffee production, the public policies directed to the coffee sector should be carefully examined before being implemented effectively, because they may cause significant effect on the employment generation and, consequently, on the state economy.

In the Espírito Santo State, the sectors related to coffee are among the five largest generators of total employments: "Robusta" first, "Arabica" third and "Coffee industry" in the fourth. Therefore, policies related to the coffee production and industrialization may cause significant social and economic impacts in this state.

In São Paulo, that produces only arabica coffee, the coffee sector and industry are, respectively, in the third and eighth position on the employment generation. This is a surprising result, due to the high degree of industrialization, involving very important sectors such as production and industrialization of sugar and alcohol, livestock, citrus, dairy products and vegetable oils.

In Paraná State, an arabica producer, characterized by small family farms, the coffee sector is the most important sector regarding employment generation. The "Robusta" sector stands out in Bahia (third largest), Rondônia (second) and Rest of Brazil (the first). 
These results highlight the importance of farming and the coffee industry for both economies, state and national as a whole.

However, more importantly, the results indicate that the impact of the implementation of public policies that act on sectors of agricultural production of coffee, arabica and robusta, and the sector of industrialization (or solubilization, roasting and grinding) should be significant on the employment generation in both economies, state and national as a whole.

\section{REFERENCES}

GUILHOTO, J.J.M. Análise de Insumo-Produto: Teoria, Fundamentos e Aplicações. Livro em Elaboração. Departamento de Economia. FEA-USP, 2007.

GUILHOTO, J. J. M.; SESSO FILHO, Umberto Antonio. Estimação da Matriz InsumoProduto a Partir de Dados Preliminares das Contas Nacionais. Revista de Economia Aplicada, São Paulo, SP, v. 9, n. 2, 2005.

IBGE - Instituto Brasileiro de Geografia e Estatística. IBGE Atualiza cálculo do produto Interno Bruto e retrata com detalhes a economia do País. http://www.ibge.gov.br/home/presidencia/noticias/nota_nova_metodologia.shtm), acesso em 2007a.

IBGE - Instituto Brasileiro de Geografia e Estatística. Pesquisa Nacional por Amostras de Domicílios.http://www.ibge.gov.br/home/estatistica/população/trabalhoerendimento/pnad200 7/default.shtm. Acesso em 2007b.

LEONTIEF, W. (1966). Input-Output Economics. New York: Oxford University Press.

MILLER, R.E., and BLAIR, P.D. Input-Output Analysis: Foundations and Extensions. Englewood Cliffs: Prentice-Hall, 1985.

VEGRO, C. L. R.; BLISKA, F. M. M. Evolução e participação da cadeia produtiva do 
café no Estado de São Paulo no agronegócio brasileiro. Capítulo 2, p.15-20. In: Prospecção de demandas na cadeia produtiva do café no Estado de São Paulo. (Orgs) BLISKA, F. M. M; GUERREIRO FILHO, O., Campinas: Instituto Agronômico. 2007, 75 p.

BLISKA, F. M. M. et al. Dinâmica fitotécnica e socioeconômica da cafeicultura brasileira. Informações Econômicas, São Paulo: Instituto de Economia Agrícola, v.39, n.1, jan. 2009, p. 15-18. 
Table 1. Direct, indirect and induced effects of employment generation, and type I and type II multipliers, expressed in the Brazilian currency - Reais, constant prices of 2002, Brazil.

\begin{tabular}{|c|c|c|c|c|c|c|c|}
\hline \multirow{2}{*}{ Sectors } & \multicolumn{5}{|c|}{ Employment generating } & \multicolumn{2}{|c|}{ Multiplier effect } \\
\hline & Direct & Indirect & Induced & Total & Rank & Type I & Type II \\
\hline Arabica coffee & 121 & 14 & 71 & 207 & 4 & 1,12 & 1,71 \\
\hline Robusta coffee & 192 & 20 & 74 & 286 & 1 & 1,11 & 1,49 \\
\hline Other agriculture and related services & 125 & 26 & 73 & 224 & 3 & 1,21 & 1,79 \\
\hline Non-metallic mineral industries & 12 & 17 & 51 & 79 & 31 & 2,48 & 6,89 \\
\hline Oil and gas & 1 & 21 & 50 & 72 & 38 & 22,82 & 76,02 \\
\hline Non-metallic mineral industries & 23 & 20 & 55 & 98 & 23 & 1,88 & 4,29 \\
\hline Steel industries & 3 & 18 & 48 & 68 & 41 & 7,59 & 25,13 \\
\hline Non-ferrous metal metallurgy & 5 & 17 & 48 & 69 & 40 & 4,69 & 15,18 \\
\hline Other metallurgic industries & 20 & 14 & 56 & 90 & 25 & 1,73 & 4,58 \\
\hline Machinery and tractors industries & 10 & 17 & 53 & 81 & 28 & 2,76 & 8,18 \\
\hline Electric equipment industries & 8 & 17 & 51 & 77 & 35 & 3,07 & 9,33 \\
\hline Electronic equipment industries & 5 & 20 & 46 & 70 & 39 & 4,63 & 13,10 \\
\hline Automobiles, trucks and buses industries & 2 & 27 & 51 & 80 & 29 & 13,34 & 36,67 \\
\hline Motors and parts of vehicles industries & 7 & 17 & 51 & 76 & 36 & 3,37 & 10,44 \\
\hline Wood and furniture industries & 35 & 28 & 59 & 123 & 17 & 1,79 & 3,48 \\
\hline Pulp and paper industries & 11 & 24 & 57 & 92 & 24 & 3,28 & 8,57 \\
\hline Rubber industry & 10 & 21 & 51 & 81 & 27 & 3,17 & 8,45 \\
\hline Chemical elements & 4 & 32 & 50 & 85 & 26 & 8,96 & 21,48 \\
\hline Refined petroleum & 1 & 18 & 39 & 57 & 43 & 24,75 & 75,72 \\
\hline Chemical industries & 6 & 21 & 48 & 74 & 37 & 4,83 & 13,45 \\
\hline Pharmaceutical and medicine industries & 6 & 20 & 53 & 79 & 32 & 4,17 & 12,61 \\
\hline Plastic industries & 12 & 17 & 48 & 77 & 34 & 2,41 & 6,31 \\
\hline Textile industries & 32 & 33 & 58 & 123 & 16 & 2,01 & 3,80 \\
\hline Clothing industries & 75 & 33 & 68 & 177 & 5 & 1,44 & 2,35 \\
\hline Footwear industries & 30 & 40 & 60 & 130 & 15 & 2,34 & 4,33 \\
\hline Coffee industries & 6 & 91 & 67 & 164 & 8 & 15,91 & 26,84 \\
\hline Other vegetables processing & 7 & 76 & 61 & 144 & 13 & 12,28 & 21,38 \\
\hline Meat industries & 7 & 99 & 65 & 171 & 6 & 14,68 & 23,73 \\
\hline Dairy products industries & 11 & 81 & 64 & 156 & 10 & 8,35 & 14,13 \\
\hline Sugar industries & 10 & 72 & 63 & 145 & 12 & 8,25 & 14,64 \\
\hline Vegetable oil mills & 1 & 100 & 63 & 165 & 7 & 87,45 & 142,12 \\
\hline Other food industries & 16 & 59 & 59 & 134 & 14 & 4,75 & 8,47 \\
\hline Miscellaneous manufacturing & 30 & 19 & 56 & 105 & 22 & 1,65 & 3,53 \\
\hline Electricity, gas and water supply & 4 & 10 & 50 & 64 & 42 & 3,70 & 16,74 \\
\hline Construction & 42 & 19 & 61 & 123 & 18 & 1,46 & 2,92 \\
\hline Wholesale and retrial trade & 74 & 11 & 74 & 158 & 9 & 1,14 & 2,15 \\
\hline Transports & 29 & 18 & 64 & 111 & 21 & 1,59 & 3,76 \\
\hline Communications & 6 & 18 & 54 & 77 & 33 & 4,01 & 13,11 \\
\hline Financial intermediation & 6 & 12 & 62 & 80 & 30 & 3,00 & 13,55 \\
\hline Personal services & 55 & 21 & 70 & 147 & 11 & 1,39 & 2,65 \\
\hline Business services & 36 & 16 & 70 & 123 & 19 & 1,45 & 3,38 \\
\hline Real estate & 4 & 2 & 44 & 51 & 44 & 1,62 & 12,86 \\
\hline Public administration & 28 & 13 & 80 & 120 & 20 & 1,45 & 4,29 \\
\hline Private households with employed persons & 149 & 19 & 77 & 245 & 2 & 1,13 & 1,64 \\
\hline
\end{tabular}

Source: Research results. 
Table 2. Direct, indirect and induced effects of employment generation, and type I and type II multipliers, expressed in the Brazilian currency - Reais, constant prices of 2002, Minas Gerais.

\begin{tabular}{|c|c|c|c|c|c|c|c|}
\hline \multirow{2}{*}{ Sectors } & \multicolumn{5}{|c|}{ Employment generating } & \multicolumn{2}{|c|}{ Multiplier effect } \\
\hline & Direct & Indirect & Induced & Total & Rank & Type I & Type II \\
\hline Arabica coffee & 117 & 14 & 83 & 214 & 2 & 1,12 & 1,84 \\
\hline Robusta coffee & 0 & 0 & 0 & 0 & 44 & 0,00 & 0,00 \\
\hline Other agriculture and related services & 72 & 35 & 80 & 188 & 4 & 1,49 & 2,60 \\
\hline Non-metallic mineral industries & 10 & 16 & 66 & 92 & 37 & 2,54 & 8,81 \\
\hline Oil and gas & 1 & 25 & 68 & 94 & 36 & 35,89 & 129,84 \\
\hline Non-metallic mineral industries & 26 & 21 & 69 & 116 & 22 & 1,83 & 4,51 \\
\hline Steel industries & 3 & 20 & 60 & 83 & 41 & 7,65 & 28,05 \\
\hline Non-ferrous metal metallurgy & 7 & 19 & 64 & 90 & 38 & 3,72 & 12,81 \\
\hline Other metallurgic industries & 21 & 16 & 70 & 108 & 24 & 1,75 & 5,02 \\
\hline Machinery and tractors industries & 14 & 20 & 69 & 103 & 25 & 2,44 & 7,30 \\
\hline Electric equipment industries & 10 & 20 & 66 & 96 & 32 & 3,00 & 9,71 \\
\hline Electronic equipment industries & 7 & 26 & 63 & 97 & 31 & 4,66 & 13,47 \\
\hline Automobiles, trucks and buses industries & 2 & 30 & 57 & 90 & 39 & 17,75 & 49,37 \\
\hline Motors and parts of vehicles industries & 8 & 21 & 67 & 95 & 33 & 3,48 & 11,48 \\
\hline Wood and furniture industries & 53 & 31 & 76 & 160 & 10 & 1,58 & 3,01 \\
\hline Pulp and paper industries & 13 & 25 & 73 & 111 & 23 & 2,88 & 8,50 \\
\hline Rubber industry & 11 & 24 & 66 & 102 & 26 & 3,08 & 8,87 \\
\hline Chemical elements & 3 & 30 & 65 & 98 & 29 & 11,90 & 35,38 \\
\hline Refined petroleum & 1 & 22 & 50 & 72 & 43 & 37,11 & 118,91 \\
\hline Chemical industries & 6 & 25 & 64 & 95 & 34 & 4,98 & 15,16 \\
\hline Pharmaceutical and medicine industries & 7 & 22 & 70 & 99 & 28 & 4,28 & 14,52 \\
\hline Plastic industries & 15 & 22 & 63 & 100 & 27 & 2,47 & 6,71 \\
\hline Textile industries & 36 & 36 & 72 & 144 & 14 & 2,00 & 4,00 \\
\hline Clothing industries & 91 & 38 & 82 & 211 & 3 & 1,41 & 2,32 \\
\hline Footwear industries & 60 & 49 & 73 & 182 & 6 & 1,81 & 3,04 \\
\hline Coffee industries & 7 & 86 & 78 & 171 & 7 & 12,66 & 23,26 \\
\hline Other vegetables processing & 10 & 60 & 73 & 143 & 15 & 7,02 & 14,37 \\
\hline Meat industries & 8 & 73 & 75 & 156 & 11 & 10,17 & 19,68 \\
\hline Dairy products industries & 14 & 80 & 68 & 162 & 9 & 6,81 & 11,75 \\
\hline Sugar industries & 10 & 54 & 74 & 138 & 16 & 6,15 & 13,18 \\
\hline Vegetable oil mills & 1 & 93 & 73 & 167 & 8 & 79,66 & 141,34 \\
\hline Other food industries & 19 & 58 & 70 & 147 & 13 & 4,05 & 7,73 \\
\hline Miscellaneous manufacturing & 40 & 22 & 73 & 135 & 19 & 1,56 & 3,38 \\
\hline Electricity, gas and water supply & 4 & 10 & 69 & 83 & 40 & 3,34 & 18,95 \\
\hline Construction & 41 & 20 & 76 & 136 & 18 & 1,48 & 3,33 \\
\hline Wholesale and retrial trade & 87 & 7 & 90 & 184 & 5 & 1,08 & 2,12 \\
\hline Transports & 24 & 18 & 75 & 118 & 21 & 1,76 & 4,85 \\
\hline Communications & 6 & 18 & 71 & 95 & 35 & 3,89 & 15,28 \\
\hline Financial intermediation & 7 & 13 & 78 & 98 & 30 & 2,89 & 14,07 \\
\hline Personal services & 51 & 23 & 80 & 153 & 12 & 1,45 & 3,03 \\
\hline Business services & 36 & 18 & 83 & 137 & 17 & 1,49 & 3,80 \\
\hline Real estate & 3 & 3 & 72 & 78 & 42 & 1,85 & 23,82 \\
\hline Public administration & 28 & 12 & 88 & 128 & 20 & 1,43 & 4,61 \\
\hline Private households with employed persons & 155 & 19 & 83 & 257 & 1 & 1,12 & 1,66 \\
\hline
\end{tabular}

Source: Research results. 
Table 3. Direct, indirect and induced effects of employment generation, and type I and type II multipliers, expressed in the Brazilian currency - Reais, constant prices of 2002, Espírito Santo.

\begin{tabular}{|c|c|c|c|c|c|c|c|}
\hline \multirow{2}{*}{ Sectors } & \multicolumn{5}{|c|}{ Employment generating } & \multicolumn{2}{|c|}{ Multiplier effect } \\
\hline & Direct & Indirect & Induced & Total & Rank & Type I & Type II \\
\hline Arabica coffee & 142 & 13 & 77 & 233 & 3 & 1,09 & 1,64 \\
\hline Robusta coffee & 177 & 17 & 76 & 270 & 1 & 1,09 & 1,52 \\
\hline Other agriculture and related services & 41 & 41 & 43 & 125 & 12 & 2,01 & 3,07 \\
\hline Non-metallic mineral industries & 10 & 9 & 52 & 71 & 31 & 1,93 & 6,98 \\
\hline Oil and gas & 1 & 19 & 47 & 67 & 36 & 18,57 & 63,05 \\
\hline Non-metallic mineral industries & 18 & 20 & 52 & 90 & 24 & 2,15 & 5,13 \\
\hline Steel industries & 2 & 15 & 42 & 59 & 42 & 7,44 & 25,57 \\
\hline Non-ferrous metal metallurgy & 5 & 15 & 43 & 63 & 40 & 4,11 & 12,92 \\
\hline Other metallurgic industries & 18 & 14 & 50 & 82 & 26 & 1,78 & 4,53 \\
\hline Machinery and tractors industries & 11 & 16 & 47 & 74 & 30 & 2,45 & 6,65 \\
\hline Electric equipment industries & 9 & 15 & 44 & 68 & 33 & 2,71 & 7,73 \\
\hline Electronic equipment industries & 5 & 15 & 34 & 55 & 43 & 3,91 & 10,36 \\
\hline Automobiles, trucks and buses industries & 3 & 21 & 37 & 60 & 41 & 9,13 & 23,19 \\
\hline Motors and parts of vehicles industries & 7 & 15 & 43 & 64 & 38 & 3,24 & 9,73 \\
\hline Wood and furniture industries & 46 & 31 & 56 & 133 & 10 & 1,66 & 2,87 \\
\hline Pulp and paper industries & 9 & 27 & 54 & 91 & 23 & 3,98 & 9,94 \\
\hline Rubber industry & 11 & 16 & 43 & 70 & 32 & 2,50 & 6,40 \\
\hline Chemical elements & 3 & 27 & 47 & 77 & 28 & 9,30 & 23,52 \\
\hline Refined petroleum & 1 & 13 & 30 & 43 & 44 & 22,60 & 71,41 \\
\hline Chemical industries & 6 & 18 & 41 & 65 & 37 & 3,81 & 10,32 \\
\hline Pharmaceutical and medicine industries & 5 & 20 & 50 & 75 & 29 & 4,73 & 14,08 \\
\hline Plastic industries & 10 & 14 & 40 & 64 & 39 & 2,37 & 6,23 \\
\hline Textile industries & 33 & 33 & 53 & 119 & 17 & 2,00 & 3,59 \\
\hline Clothing industries & 64 & 37 & 61 & 162 & 7 & 1,57 & 2,53 \\
\hline Footwear industries & 61 & 48 & 53 & 162 & 8 & 1,78 & 2,66 \\
\hline Coffee industries & 7 & 116 & 69 & 192 & 4 & 18,44 & 28,83 \\
\hline Other vegetables processing & 10 & 49 & 49 & 108 & 20 & 5,82 & 10,58 \\
\hline Meat industries & 6 & 97 & 67 & 170 & 5 & 17,96 & 29,58 \\
\hline Dairy products industries & 11 & 51 & 48 & 111 & 18 & 5,77 & 10,26 \\
\hline Sugar industries & 7 & 49 & 52 & 109 & 19 & 7,70 & 14,80 \\
\hline Vegetable oil mills & 1 & 101 & 62 & 164 & 6 & 124,42 & 199,81 \\
\hline Other food industries & 15 & 55 & 54 & 124 & 14 & 4,70 & 8,31 \\
\hline Miscellaneous manufacturing & 28 & 20 & 50 & 97 & 22 & 1,70 & 3,48 \\
\hline Electricity, gas and water supply & 4 & 12 & 51 & 67 & 34 & 3,78 & 15,27 \\
\hline Construction & 48 & 17 & 60 & 125 & 13 & 1,35 & 2,61 \\
\hline Wholesale and retrial trade & 73 & 10 & 75 & 158 & 9 & 1,13 & 2,16 \\
\hline Transports & 23 & 14 & 64 & 102 & 21 & 1,61 & 4,35 \\
\hline Communications & 5 & 15 & 60 & 80 & 27 & 3,99 & 15,59 \\
\hline Financial intermediation & 7 & 13 & 68 & 88 & 25 & 2,85 & 12,53 \\
\hline Personal services & 44 & 21 & 66 & 132 & 11 & 1,47 & 2,97 \\
\hline Business services & 36 & 16 & 69 & 121 & 16 & 1,44 & 3,37 \\
\hline Real estate & 3 & 3 & 61 & 67 & 35 & 1,90 & 19,79 \\
\hline Public administration & 30 & 12 & 80 & 123 & 15 & 1,39 & 4,02 \\
\hline Private households with employed persons & 147 & 20 & 70 & 237 & 2 & 1,13 & 1,61 \\
\hline
\end{tabular}

Source: Research results. 
Table 4. Direct, indirect and induced effects of employment generation, and type I and type II multipliers, expressed in the Brazilian currency - Reais, constant prices of 2002, São Paulo.

\begin{tabular}{|c|c|c|c|c|c|c|c|}
\hline \multirow{2}{*}{ Sectors } & \multicolumn{5}{|c|}{ Employment generating } & \multicolumn{2}{|c|}{ Multiplier effect } \\
\hline & Direct & Indirect & Induced & Total & Rank & Type I & Type II \\
\hline Arábica coffee & 93 & 9 & 62 & 164 & 3 & 1,10 & 1,77 \\
\hline Robusta coffee & 0 & 0 & 0 & 0 & 44 & 0,00 & 0,00 \\
\hline Other agriculture and related services & 64 & 17 & 64 & 145 & 5 & 1,27 & 2,28 \\
\hline Non-metallic mineral industries & 13 & 15 & 39 & 66 & 35 & 2,14 & 5,12 \\
\hline Oil and gas & 1 & 19 & 40 & 60 & 40 & 29,22 & 87,74 \\
\hline Non-metallic mineral industries & 20 & 19 & 48 & 87 & 22 & 1,92 & 4,30 \\
\hline Steel industries & 3 & 16 & 42 & 60 & 39 & 6,94 & 22,57 \\
\hline Non-ferrous metal metallurgy & 5 & 16 & 42 & 64 & 37 & 3,96 & 11,77 \\
\hline Other metallurgic industries & 18 & 14 & 50 & 82 & 24 & 1,79 & 4,60 \\
\hline Machinery and tractors industries & 11 & 16 & 48 & 76 & 26 & 2,48 & 6,80 \\
\hline Electric equipment industries & 8 & 16 & 46 & 70 & 31 & 2,91 & 8,39 \\
\hline Electronic equipment industries & 6 & 18 & 40 & 64 & 36 & 4,17 & 11,02 \\
\hline Automobiles, trucks and buses industries & 2 & 25 & 46 & 72 & 27 & 12,36 & 33,48 \\
\hline Motors and parts of vehicles industries & 7 & 17 & 46 & 69 & 32 & 3,33 & 9,81 \\
\hline Wood and furniture industries & 39 & 24 & 50 & 113 & 14 & 1,62 & 2,93 \\
\hline Pulp and paper industries & 10 & 24 & 50 & 84 & 23 & 3,31 & 8,18 \\
\hline Rubber industry & 10 & 22 & 49 & 80 & 25 & 3,31 & 8,39 \\
\hline Chemical elements & 3 & 22 & 43 & 68 & 33 & 7,92 & 21,30 \\
\hline Refined petroleum & 1 & 16 & 34 & 51 & 42 & 25,53 & 76,32 \\
\hline Chemical industries & 5 & 21 & 45 & 71 & 29 & 5,08 & 13,96 \\
\hline Pharmaceutical and medicine industries & 6 & 20 & 45 & 72 & 28 & 4,38 & 11,96 \\
\hline Plastic industries & 11 & 16 & 43 & 71 & 30 & 2,43 & 6,22 \\
\hline Textile industries & 27 & 33 & 51 & 111 & 16 & 2,21 & 4,07 \\
\hline Clothing industries & 68 & 32 & 58 & 158 & 4 & 1,47 & 2,31 \\
\hline Footwear industries & 45 & 38 & 52 & 134 & 6 & 1,84 & 2,99 \\
\hline Coffee industries & 6 & 69 & 59 & 133 & 8 & 13,23 & 23,69 \\
\hline Other vegetables processing & 8 & 65 & 57 & 130 & 9 & 9,63 & 17,15 \\
\hline Meat industries & 6 & 54 & 57 & 117 & 12 & 9,85 & 19,11 \\
\hline Dairy products industries & 11 & 49 & 55 & 115 & 13 & 5,41 & 10,40 \\
\hline Sugar industries & 8 & 49 & 55 & 112 & 15 & 6,76 & 13,33 \\
\hline Vegetable oil mills & 1 & 109 & 62 & 171 & 2 & 118,28 & 185,24 \\
\hline Other food industries & 15 & 56 & 52 & 123 & 11 & 4,70 & 8,17 \\
\hline Miscellaneous manufacturing & 31 & 19 & 48 & 98 & 20 & 1,62 & 3,18 \\
\hline Electricity, gas and water supply & 3 & 10 & 40 & 53 & 41 & 4,15 & 17,09 \\
\hline Construction & 42 & 15 & 53 & 110 & 17 & 1,36 & 2,61 \\
\hline Wholesale and retrial trade & 62 & 10 & 61 & 134 & 7 & 1,16 & 2,15 \\
\hline Transports & 28 & 13 & 55 & 95 & 21 & 1,47 & 3,47 \\
\hline Communications & 6 & 13 & 44 & 63 & 38 & 3,42 & 11,34 \\
\hline Financial intermediation & 5 & 10 & 52 & 67 & 34 & 3,00 & 13,19 \\
\hline Personal services & 49 & 20 & 58 & 127 & 10 & 1,41 & 2,59 \\
\hline Business services & 29 & 14 & 61 & 103 & 19 & 1,48 & 3,59 \\
\hline Real estate & 4 & 2 & 33 & 38 & 43 & 1,64 & 10,90 \\
\hline Public administration & 25 & 10 & 71 & 107 & 18 & 1,42 & 4,26 \\
\hline Private households with employed persons & 122 & 17 & 68 & 207 & 1 & 1,14 & 1,69 \\
\hline
\end{tabular}

Source: Research results. 
Table 5. Direct, indirect and induced effects of employment generation, and type I and type II multipliers, expressed in the Brazilian currency - Reais, constant prices of 2002, Paraná.

\begin{tabular}{|c|c|c|c|c|c|c|c|}
\hline \multirow{2}{*}{ Sectors } & \multicolumn{5}{|c|}{ Employment generating } & \multicolumn{2}{|c|}{ Multiplier effect } \\
\hline & Direct & Indirect & Induced & Total & Rank & Type I & Type II \\
\hline Arabica coffee & 154 & 19 & 66 & 238 & 1 & 1,13 & 1,55 \\
\hline Robusta coffee & 0 & 0 & 0 & 0 & 44 & 0,00 & 0,00 \\
\hline Other agriculture and related services & 95 & 23 & 68 & 186 & 3 & 1,24 & 1,95 \\
\hline Non-metallic mineral industries & 23 & 22 & 47 & 92 & 23 & 1,95 & 4,01 \\
\hline Oil and gas & 1 & 25 & 46 & 72 & 35 & 20,29 & 55,75 \\
\hline Non-metallic mineral industries & 18 & 19 & 50 & 88 & 24 & 2,07 & 4,88 \\
\hline Steel industries & 3 & 18 & 44 & 64 & 41 & 7,76 & 24,13 \\
\hline Non-ferrous metal metallurgy & 8 & 17 & 46 & 71 & 36 & 3,28 & 9,31 \\
\hline Other metallurgic industries & 24 & 16 & 53 & 93 & 22 & 1,67 & 3,85 \\
\hline Machinery and tractors industries & 6 & 18 & 50 & 74 & 34 & 3,99 & 12,28 \\
\hline Electric equipment industries & 7 & 16 & 47 & 71 & 37 & 3,46 & 10,54 \\
\hline Electronic equipment industries & 7 & 20 & 41 & 68 & 39 & 3,72 & 9,28 \\
\hline Automobiles, trucks and buses industries & 2 & 27 & 47 & 76 & 31 & 13,38 & 35,21 \\
\hline Motors and parts of vehicles industries & 10 & 17 & 48 & 75 & 32 & 2,78 & 7,62 \\
\hline Wood and furniture industries & 24 & 27 & 55 & 106 & 19 & 2,12 & 4,43 \\
\hline Pulp and paper industries & 8 & 25 & 51 & 84 & 26 & 3,99 & 10,24 \\
\hline Rubber industry & 11 & 21 & 47 & 79 & 30 & 2,87 & 7,06 \\
\hline Chemical elements & 4 & 29 & 48 & 82 & 27 & 9,06 & 22,34 \\
\hline Refined petroleum & 1 & 18 & 37 & 56 & 42 & 20,88 & 61,22 \\
\hline Chemical industries & 10 & 22 & 43 & 75 & 33 & 3,29 & 7,79 \\
\hline Pharmaceutical and medicine industries & 11 & 23 & 52 & 86 & 25 & 3,16 & 7,97 \\
\hline Plastic industries & 14 & 15 & 42 & 71 & 38 & 2,10 & 5,13 \\
\hline Textile industries & 37 & 30 & 49 & 116 & 17 & 1,81 & 3,15 \\
\hline Clothing industries & 80 & 33 & 61 & 175 & 5 & 1,41 & 2,17 \\
\hline Footwear industries & 23 & 42 & 55 & 119 & 16 & 2,84 & 5,25 \\
\hline Coffee industries & 4 & 90 & 68 & 162 & 6 & 22,11 & 37,93 \\
\hline Other vegetables processing & 6 & 66 & 57 & 129 & 13 & 11,89 & 21,41 \\
\hline Meat industries & 10 & 100 & 65 & 175 & 4 & 11,01 & 17,49 \\
\hline Dairy products industries & 19 & 73 & 60 & 152 & 7 & 4,76 & 7,86 \\
\hline Sugar industries & 16 & 61 & 60 & 137 & 11 & 4,87 & 8,66 \\
\hline Vegetable oil mills & 1 & 83 & 59 & 143 & 9 & 74,53 & 126,55 \\
\hline Other food industries & 13 & 56 & 55 & 124 & 14 & 5,26 & 9,46 \\
\hline Miscellaneous manufacturing & 25 & 20 & 51 & 96 & 21 & 1,82 & 3,85 \\
\hline Electricity, gas and water supply & 3 & 6 & 55 & 64 & 40 & 3,49 & 25,13 \\
\hline Construction & 35 & 16 & 60 & 111 & 18 & 1,45 & 3,14 \\
\hline Wholesale and retrial trade & 53 & 15 & 67 & 136 & 12 & 1,28 & 2,54 \\
\hline Transports & 22 & 20 & 58 & 99 & 20 & 1,91 & 4,60 \\
\hline Communications & 7 & 23 & 51 & 80 & 28 & 4,33 & 11,81 \\
\hline Financial intermediation & 7 & 13 & 59 & 79 & 29 & 2,99 & 11,86 \\
\hline Personal services & 52 & 23 & 66 & 141 & 10 & 1,45 & 2,74 \\
\hline Business services & 59 & 19 & 66 & 145 & 8 & 1,33 & 2,45 \\
\hline Real estate & 4 & 2 & 44 & 50 & 43 & 1,58 & 13,14 \\
\hline Public administration & 33 & 16 & 74 & 123 & 15 & 1,48 & 3,71 \\
\hline Private households with employed persons & 138 & 19 & 72 & 230 & 2 & 1,14 & 1,66 \\
\hline
\end{tabular}

Source: Research results. 
Table 6. Direct, indirect and induced effects of employment generation, and type I and type II multipliers, expressed in the Brazilian currency - Reais, constant prices of 2002, Bahia.

\begin{tabular}{|c|c|c|c|c|c|c|c|}
\hline \multirow{2}{*}{ Sectors } & \multicolumn{5}{|c|}{ Employment generating } & \multicolumn{2}{|c|}{ Multiplier effect } \\
\hline & Direct & Indirect & Induced & Total & Rank & Type I & Type II \\
\hline Arábica coffee & 180 & 33 & 109 & 321 & 6 & 1,18 & 1,79 \\
\hline Robusta coffee & 232 & 40 & 131 & 404 & 3 & 1,17 & 1,74 \\
\hline Other agriculture and related services & 352 & 23 & 150 & 525 & 1 & 1,07 & 1,49 \\
\hline Non-metallic mineral industries & 22 & 20 & 120 & 162 & 27 & 1,88 & 7,25 \\
\hline Oil and gas & 2 & 35 & 102 & 138 & 39 & 17,70 & 66,46 \\
\hline Non-metallic mineral industries & 49 & 19 & 133 & 202 & 16 & 1,38 & 4,08 \\
\hline Steel industries & 3 & 22 & 110 & 135 & 41 & 8,86 & 47,40 \\
\hline Non-ferrous metal metallurgy & 3 & 19 & 117 & 139 & 38 & 6,58 & 41,75 \\
\hline Other metallurgic industries & 16 & 12 & 135 & 163 & 25 & 1,77 & 10,13 \\
\hline Machinery and tractors industries & 15 & 17 & 128 & 160 & 29 & 2,14 & 10,50 \\
\hline Electric equipment industries & 12 & 20 & 124 & 156 & 32 & 2,68 & 13,23 \\
\hline Electronic equipment industries & 9 & 28 & 106 & 143 & 36 & 4,24 & 16,66 \\
\hline Automobiles, trucks and buses industries & 2 & 36 & 90 & 129 & 43 & 16,75 & 55,61 \\
\hline Motors and parts of vehicles industries & 12 & 21 & 122 & 155 & 33 & 2,81 & 13,19 \\
\hline Wood and furniture industries & 54 & 27 & 141 & 222 & 14 & 1,50 & 4,14 \\
\hline Pulp and paper industries & 16 & 31 & 131 & 177 & 24 & 2,99 & 11,39 \\
\hline Rubber industry & 16 & 29 & 116 & 161 & 28 & 2,85 & 10,18 \\
\hline Chemical elements & 7 & 37 & 114 & 159 & 30 & 6,36 & 22,80 \\
\hline Refined petroleum & 1 & 24 & 67 & 91 & 44 & 30,28 & 113,40 \\
\hline Chemical industries & 8 & 29 & 102 & 138 & 40 & 4,63 & 17,54 \\
\hline Pharmaceutical and medicine industries & 5 & 17 & 133 & 155 & 34 & 4,15 & 29,47 \\
\hline Plastic industries & 10 & 21 & 104 & 135 & 42 & 3,16 & 13,75 \\
\hline Textile industries & 40 & 19 & 141 & 199 & 18 & 1,47 & 5,01 \\
\hline Clothing industries & 104 & 23 & 148 & 275 & 9 & 1,22 & 2,64 \\
\hline Footwear industries & 13 & 27 & 138 & 178 & 23 & 3,15 & 14,12 \\
\hline Coffee industries & 7 & 90 & 99 & 197 & 20 & 13,75 & 27,76 \\
\hline Other vegetables processing & 11 & 146 & 130 & 287 & 8 & 14,48 & 26,47 \\
\hline Meat industries & 6 & 189 & 136 & 331 & 4 & 31,41 & 53,25 \\
\hline Dairy products industries & 6 & 129 & 111 & 246 & 11 & 21,20 & 38,69 \\
\hline Sugar industries & 14 & 111 & 129 & 253 & 10 & 9,06 & 18,42 \\
\hline Vegetable oil mills & 2 & 202 & 126 & 330 & 5 & 111,16 & 180,18 \\
\hline Other food industries & 19 & 71 & 110 & 200 & 17 & 4,74 & 10,56 \\
\hline Miscellaneous manufacturing & 45 & 16 & 136 & 196 & 21 & 1,35 & 4,39 \\
\hline Electricity, gas and water supply & 5 & 14 & 120 & 139 & 37 & 3,59 & 25,96 \\
\hline Construction & 50 & 26 & 112 & 188 & 22 & 1,52 & 3,78 \\
\hline Wholesale and retrial trade & 132 & 7 & 154 & 294 & 7 & 1,05 & 2,22 \\
\hline Transports & 48 & 24 & 127 & 198 & 19 & 1,50 & 4,15 \\
\hline Communications & 6 & 22 & 130 & 158 & 31 & 4,85 & 27,48 \\
\hline Financial intermediation & 7 & 12 & 142 & 162 & 26 & 2,68 & 21,98 \\
\hline Personal services & 70 & 24 & 138 & 232 & 12 & 1,34 & 3,31 \\
\hline Business services & 65 & 14 & 150 & 229 & 13 & 1,21 & 3,53 \\
\hline Real estate & 4 & 2 & 144 & 150 & 35 & 1,46 & 36,83 \\
\hline Public administration & 40 & 17 & 147 & 204 & 15 & 1,43 & 5,14 \\
\hline Private households with employed persons & 239 & 17 & 148 & 404 & 2 & 1,07 & 1,69 \\
\hline
\end{tabular}

Source: Research results. 
Table 7. Direct, indirect and induced effects of employment generation, and type I and type II multipliers, expressed in the Brazilian currency - Reais, constant prices of 2002, Rondônia.

\begin{tabular}{|c|c|c|c|c|c|c|c|}
\hline \multirow{2}{*}{ Sectors } & \multicolumn{5}{|c|}{ Employment generating } & \multicolumn{2}{|c|}{ Multiplier effect } \\
\hline & Direct & Indirect & Induced & Total & Rank & Type I & Type II \\
\hline Arábica coffee & 0 & 0 & 0 & 0 & 44 & 0,00 & 0,00 \\
\hline Robusta coffee & 193 & 35 & 119 & 346 & 2 & 1,18 & 1,80 \\
\hline Other agriculture and related services & 105 & 20 & 117 & 242 & 6 & 1,19 & 2,30 \\
\hline Non-metallic mineral industries & 8 & 26 & 82 & 115 & 38 & 4,29 & 14,66 \\
\hline Oil and gas & 1 & 34 & 95 & 130 & 29 & 61,43 & 228,39 \\
\hline Non-metallic mineral industries & 45 & 34 & 92 & 171 & 18 & 1,74 & 3,77 \\
\hline Steel industries & 2 & 25 & 76 & 103 & 42 & 14,35 & 55,25 \\
\hline Non-ferrous metal metallurgy & 4 & 26 & 84 & 114 & 40 & 7,58 & 28,71 \\
\hline Other metallurgic industries & 17 & 24 & 94 & 135 & 27 & 2,39 & 7,87 \\
\hline Machinery and tractors industries & 20 & 28 & 89 & 137 & 25 & 2,43 & 6,96 \\
\hline Electric equipment industries & 9 & 28 & 85 & 122 & 35 & 4,14 & 13,68 \\
\hline Electronic equipment industries & 5 & 36 & 83 & 124 & 34 & 8,63 & 26,12 \\
\hline Automobiles, trucks and buses industries & 3 & 43 & 82 & 128 & 31 & 16,01 & 44,67 \\
\hline Motors and parts of vehicles industries & 5 & 29 & 85 & 118 & 37 & 6,89 & 24,38 \\
\hline Wood and furniture industries & 57 & 42 & 97 & 196 & 9 & 1,73 & 3,43 \\
\hline Pulp and paper industries & 11 & 36 & 99 & 146 & 23 & 4,19 & 13,01 \\
\hline Rubber industry & 19 & 29 & 79 & 127 & 32 & 2,58 & 6,84 \\
\hline Chemical elements & 5 & 39 & 87 & 131 & 28 & 8,92 & 26,46 \\
\hline Refined petroleum & 1 & 25 & 55 & 80 & 43 & 46,51 & 147,68 \\
\hline Chemical industries & 5 & 33 & 83 & 121 & 36 & 7,77 & 24,80 \\
\hline Pharmaceutical and medicine industries & 4 & 32 & 93 & 129 & 30 & 8,60 & 30,92 \\
\hline Plastic industries & 11 & 28 & 75 & 115 & 39 & 3,45 & 10,03 \\
\hline Textile industries & 65 & 54 & 93 & 212 & 7 & 1,84 & 3,27 \\
\hline Clothing industries & 150 & 46 & 90 & 287 & 3 & 1,31 & 1,91 \\
\hline Footwear industries & 19 & 49 & 85 & 153 & 21 & 3,61 & 8,18 \\
\hline Coffee industries & 9 & 147 & 107 & 263 & 5 & 17,53 & 29,58 \\
\hline Other vegetables processing & 12 & 78 & 104 & 194 & 10 & 7,45 & 15,97 \\
\hline Meat industries & 6 & 105 & 83 & 194 & 12 & 17,26 & 30,12 \\
\hline Dairy products industries & 8 & 87 & 80 & 175 & 15 & 12,06 & 22,31 \\
\hline Sugar industries & 14 & 68 & 98 & 181 & 14 & 5,97 & 13,12 \\
\hline Vegetable oil mills & 2 & 102 & 100 & 204 & 8 & 57,17 & 111,97 \\
\hline Other food industries & 13 & 68 & 90 & 172 & 17 & 6,07 & 12,80 \\
\hline Miscellaneous manufacturing & 27 & 32 & 93 & 151 & 22 & 2,18 & 5,65 \\
\hline Electricity, gas and water supply & 5 & 19 & 89 & 113 & 41 & 5,20 & 24,83 \\
\hline Construction & 33 & 24 & 101 & 158 & 20 & 1,71 & 4,73 \\
\hline Wholesale and retrial trade & 147 & 4 & 132 & 282 & 4 & 1,03 & 1,93 \\
\hline Transports & 42 & 22 & 106 & 170 & 19 & 1,52 & 4,02 \\
\hline Communications & 7 & 23 & 105 & 135 & 26 & 4,07 & 18,25 \\
\hline Financial intermediation & 8 & 13 & 117 & 138 & 24 & 2,59 & 16,64 \\
\hline Personal services & 56 & 24 & 114 & 194 & 11 & 1,43 & 3,46 \\
\hline Business services & 51 & 11 & 124 & 187 & 13 & 1,22 & 3,66 \\
\hline Real estate & 5 & 1 & 120 & 126 & 33 & 1,16 & 25,95 \\
\hline Public administration & 35 & 14 & 125 & 174 & 16 & 1,40 & 5,00 \\
\hline Private households with employed persons & 228 & 17 & 121 & 366 & 1 & 1,07 & 1,61 \\
\hline
\end{tabular}

Source: Research results. 
Table 8. Direct, indirect and induced effects of employment generation, and type I and type II multipliers, expressed in the Brazilian currency - Reais, constant prices of 2002, Other States.

\begin{tabular}{|c|c|c|c|c|c|c|c|}
\hline \multirow{2}{*}{ Sectors } & \multicolumn{5}{|c|}{ Employment generating } & \multicolumn{2}{|c|}{ Multiplier effect } \\
\hline & Direct & Indirect & Induced & Total & Rank & Type I & Type II \\
\hline Arábica coffee & 201 & 22 & 71 & 294 & 2 & 1,11 & 1,46 \\
\hline Robusta coffee & 293 & 39 & 63 & 395 & 1 & 1,13 & 1,35 \\
\hline Other agriculture and related services & 148 & 27 & 75 & 250 & 4 & 1,19 & 1,69 \\
\hline Non-metallic mineral industries & 12 & 20 & 50 & 82 & 31 & 2,72 & 7,06 \\
\hline Oil and gas & 1 & 22 & 50 & 72 & 38 & 25,08 & 80,37 \\
\hline Non-metallic mineral industries & 26 & 20 & 57 & 102 & 23 & 1,78 & 4,01 \\
\hline Steel industries & 3 & 18 & 50 & 70 & 40 & 7,83 & 27,26 \\
\hline Non-ferrous metal metallurgy & 3 & 17 & 47 & 67 & 41 & 6,04 & 19,72 \\
\hline Other metallurgic industries & 22 & 14 & 60 & 95 & 24 & 1,65 & 4,38 \\
\hline Machinery and tractors industries & 8 & 17 & 55 & 81 & 32 & 3,05 & 9,59 \\
\hline Electric equipment industries & 8 & 18 & 54 & 79 & 35 & 3,23 & 10,04 \\
\hline Electronic equipment industries & 5 & 20 & 46 & 71 & 39 & 5,26 & 15,13 \\
\hline Automobiles, trucks and buses industries & 3 & 28 & 57 & 88 & 27 & 11,75 & 33,51 \\
\hline Motors and parts of vehicles industries & 7 & 17 & 53 & 76 & 36 & 3,50 & 11,25 \\
\hline Wood and furniture industries & 35 & 27 & 61 & 123 & 20 & 1,76 & 3,48 \\
\hline Pulp and paper industries & 12 & 24 & 58 & 94 & 25 & 3,06 & 8,02 \\
\hline Rubber industry & 9 & 21 & 53 & 84 & 29 & 3,27 & 9,06 \\
\hline Chemical elements & 5 & 33 & 51 & 89 & 26 & 7,47 & 17,60 \\
\hline Refined petroleum & 1 & 19 & 40 & 60 & 43 & 22,85 & 69,92 \\
\hline Chemical industries & 5 & 21 & 50 & 76 & 37 & 5,01 & 14,50 \\
\hline Pharmaceutical and medicine industries & 7 & 19 & 57 & 83 & 30 & 3,88 & 12,38 \\
\hline Plastic industries & 13 & 19 & 52 & 84 & 28 & 2,43 & 6,41 \\
\hline Textile industries & 37 & 35 & 59 & 131 & 15 & 1,94 & 3,55 \\
\hline Clothing industries & 78 & 33 & 71 & 182 & 5 & 1,43 & 2,34 \\
\hline Footwear industries & 25 & 40 & 61 & 126 & 17 & 2,58 & 4,99 \\
\hline Coffee industries & 8 & 89 & 70 & 167 & 8 & 11,97 & 20,55 \\
\hline Other vegetables processing & 6 & 77 & 62 & 144 & 13 & 14,67 & 25,66 \\
\hline Meat industries & 7 & 107 & 66 & 180 & 6 & 16,21 & 25,52 \\
\hline Dairy products industries & 10 & 86 & 65 & 161 & 10 & 9,85 & 16,56 \\
\hline Sugar industries & 12 & 73 & 65 & 150 & 12 & 6,87 & 12,09 \\
\hline Vegetable oil mills & 1 & 113 & 65 & 179 & 7 & 84,89 & 133,38 \\
\hline Other food industries & 16 & 62 & 61 & 140 & 14 & 4,82 & 8,55 \\
\hline Miscellaneous manufacturing & 27 & 19 & 58 & 104 & 22 & 1,69 & 3,83 \\
\hline Electricity, gas and water supply & 4 & 11 & 48 & 64 & 42 & 3,69 & 14,98 \\
\hline Construction & 42 & 21 & 62 & 126 & 18 & 1,51 & 2,96 \\
\hline Wholesale and retrial trade & 78 & 11 & 76 & 165 & 9 & 1,14 & 2,11 \\
\hline Transports & 32 & 20 & 65 & 117 & 21 & 1,63 & 3,66 \\
\hline Communications & 6 & 21 & 53 & 80 & 34 & 4,52 & 13,25 \\
\hline Financial intermediation & 6 & 13 & 61 & 80 & 33 & 3,04 & 12,61 \\
\hline Personal services & 60 & 22 & 73 & 155 & 11 & 1,36 & 2,58 \\
\hline Business services & 42 & 19 & 70 & 131 & 16 & 1,44 & 3,11 \\
\hline Real estate & 5 & 3 & 40 & 48 & 44 & 1,56 & 10,36 \\
\hline Public administration & 28 & 14 & 81 & 123 & 19 & 1,50 & 4,43 \\
\hline Private households with employed persons & 162 & 20 & 79 & 261 & 3 & 1,12 & 1,61 \\
\hline
\end{tabular}

Source: Research results. 